\title{
SOSYAL MEDYA VE GÜVEN: HÜKÜMET, SIVIL TOPLUM ÖRGÜTLERI VE TICARi KURULUŞLARA YÖNELIK AMPIRIK BIRR ARAŞTIRMA
}

\author{
Arş. Gör. Dr. Aybike PELENK ÖZEL \\ Kocaeli Üniversitesi İletişim Fakültesi Halkla Illişkiler ve Tanıtım Bölümü
}

\section{Özet}

Sosyal medyanın bireyler, gruplar, kurumlar ve toplumsal yapılar üzerinde giderek artan etkisi ve yaygınlaşma hızı bu araçlara duyulan güven düzeyini ve inanılırlığını tartışmayı gerektirmektedir. Kullanıcılarının çeşitliği, kullanım dilinin ve olanaklarının evrenselliği sosyal medyayı hem daha ulaşılır kılmakta hem de etkinliğini artırmaktadır. Güven kavramı ise tüm ilişki biçimleri içinde önemli bir yer teşkil etmekte, bireyler, gruplar ve kurumlar arasında açıklığı sağlayarak, çatışmalara yönelik çözümler sunmakta, toplumsal dayanışmayı sağlayarak, kurumların fonksiyonlarını sağlıklı bir şekilde yerine getirmesinde önemli bir rol oynamaktadır.

Sosyal medyanın kullanıcılar tarafından geleneksel kitle iletişim araçlarına kıyasla ne ölçüde inanılır ve güvenilir bulunduğu bir merak ve tartışma konusudur. Buradan hareketle toplumsal yap1 üzerinde etkili olduğu düşünülen hükümet, sivil toplum örgütleri ve ticari kuruluşlara yönelik bilgi edinmede sosyal medyanın genç kanaat önderleri tarafından ne ölçüde güvenilir ve inanılır görüldüğü, bu araçları kullanım sıklığı ve geleneksel medya ve diğer araçlarla karşılaştırıldığında sosyal medyanın bir bilgi kaynağı olarak nasıl değerlendirildiği araştırmanın temel sorunsalını oluşturmaktadır.

Anahar sözcükler: sosyal medya, güven, kaynă̆ın inanılırlı̆̆g, hükümet, stö, ticari kuruluşlar. 


\title{
Social Media and Trust: An Empirical Research Directed to Government, Non- Governmental Organizations and Business
}

\begin{abstract}
Increasingly social media effects and spreading rate on individuals, institutions and social structures requires trust level and credibility towards these means. Variety of users, coomun language of use, universality of opportunities make the social media accessible and efficient. Trust provides clarity between individuals, groups and institutions, solutions for conflicts, social solidarity, and play an important role to make the institutions fulfill their functions in a healty way.

The subject of debate what extent the social media credible and trustable compared to traditional mass media. From this point of view the main problematic of this research is what extent social media is credible and trustable to get information about government, nongovernmental organizations and business by young opinion elits and also frequency of use, the evuluation of social media compared to traditional media and other means as a source of getting information about government, non-governmental organizations and business that believed to be effective on social structure.
\end{abstract}

Keywords: social media, trust, source credibility, government, ngo, business.

\section{Giriş}

Sosyal hareketlere katılım, seçim işlemleri, siyasal partiler, gönüllü kuruluşlara katılım, tüketim davranışları, medya tüketimi, iletişim çaba ve etkinlikleri, kişilerarası ilişkiler, sistem ve ağlar, toplumsal yapı içinde varolan kurum ve kuruluşlar, yapılar, bu yapılar içinde yer alan aktörlerle ilişkiler temel olarak güven aracılığıyla sağlanmaktadır. Güven, bireyin varoluşuyla ve dünyayı algılayış sürecinde temel güvenle başlayan, diğer birey ve gruplarla olan kişilerarası güven ilişkileriyle somutlaşan, sosyal güven aracılığıyla modern yaşam içindeki yapılar, sistemler ve ağlara yönelik olarak gelişen bir yapıyı olanaklı kılmaktadır.

Ortak bir yaşamın içinde yer alan bütün bireyler hükümetin, ekonominin, teknolojinin, bilimin, iletişim alanının, sosyal alanların, ticaretin ve diğer alanların nüfuz alanını temsil eden tüm eylemlerin kendi yararlarına yönelik olduğuna inanmak ve güvenmek zorundadırlar. 
Güven olmaksızın toplumların ayakta kalması ve sistemlerin sürekliliği olanaklı görünmemektedir. Sistemler, kurumlar ve aktörler çeşitlendikçe diğerleriyle olan işbirliğine bağımlılık büyüdükçe, onların inanılır ve güvenilir olduklarına yönelik olarak duyulan güvenin önemi de artmaktadır. Yeni bir alan olan ve insan ilişkilerinde önemli bir belirleyici olan sosyal medyayı kullanım ve sosyal medyaya yönelik güven bu bağlamda oldukça önem taşımaktadır. Geleneksel kitle iletişim araçlarının ötesine geçerek hızlı bir yükselişle çeşitli grup ve yaştaki insanların alışverişten siyasete, spor taraftarlığından aktivizme, kültürel etkinliklerden oy verme davranışına kadar birçok faaliyet ve iş yapış biçimlerine yön veren, sosyal yaşam içindeki birçok tutum ve davranışı etkileyen sosyal ağ paylaşım siteleri, bir diğer adıyla sosyal medya günümüzde en çok tartışılan alanlardan biridir. Hem kişiler arası hem de kurumlar arası iletişim akışını geleneksel kitle iletişim araçlarından daha hızlı, daha etken ve etkili bir şekilde gerçekleştirdiği düşünülen sosyal ağ paylaşım siteleri aracılığıyla bireyler birçok kişi, grup ve kuruma ulaşmakta, toplumsal olaylara tepkisini yansıtmakta, önemli bir bilgi edinme kaynağı olarak kullanmaktadırlar. Buradan hareketle toplumsal yap1 üzerinde etkili olan sivil toplum örgütleri, hükümet ve ticari kuruluşlara yönelik bilgi edinmede sosyal ağ paylaşım sitelerinin genç kanaat önderleri tarafından ne ölçüde inanılır ve güvenilir bulunduğu, geleneksel kitle iletişim araçları ve kişiler arası iletişim biçimleriyle karşılaştırıldığında ne ölçüde etkili ve güvenilir olduğu araştırmanın sorunsalını oluşturmaktadır.

\section{Güven Kavramı}

Güvenle ilgili olarak yapılan birçok tanım bulunmakla birlikte genel olarak sosyal bilimler literatürü güveni, bir toplumda yaşayan bireylerin birbirlerine, içinde yaşadıkları sistemlerin kurallarına ve kurumlarına yönelik olarak, sözkonusu birey, kurum veya kuralların rollerini ve işlevlerini belirlenen doğrultuda en iyi şekilde yapacaklarına duyulan inanç olarak tanımlanmaktadır (Demir ve Acar, 2005: 177). Güvenin temel anlamı, Oxford İngilizce sözlüğünde ise bir kişi ya da şeyin kalitesine ya da bir ifadenin gerçekliğine veya niteliklerine inanma-itimat etme (confidence) ya da bel bağlama şeklinde tanımlanmaktadır (Misztal, 1996: 16).

Güven çok katmanlı ve geniş boyutlu bir kavram olup sosyoloji, psikoloji, ekonomi, siyaset, antropoloji, tarih, iletişim gibi farklı alan ve disiplinlerin konusu olmuştur. Her bir alan, güven olgusuna kendi perspektifinden yaklaşmış ancak güvenle ilgili yapılan bütün çalışmalar 
birbirinden beslenmiştir. Güven olgusuna ilişkin olarak ortaya çıkan literatür çok katmanlı bir yap1 özelliği göstermektedir. Hosmer de bunu destekler biçimde çoğu ekonomist, psikolog, sosyolog ve yönetim teorisyeninin insan etkinliklerini yönetme ve yönlendirmede güvenin önemi konusunda birleştiklerini ifade etmektedir (Hosmer, 1995: 379). Psikoloji alanındaki kişilik kuramcıları güveni bireysel farklılıklarla vurgulamakta, güven ve güvensizliği tek bir sürecin iki karşıt boyutu olarak görmektedirler. Sosyal psikoloji alanı, eş zamanlı olarak güven ve güvensizlik olarak tanımlanan birbiriyle çatışan psikolojik durumların geçici ve değişken olduğunu vurgulamaktadır. Sosyoloji alanı ise güven ve güvensizliğin önemli olduğunu, toplumsal karmaşa ve belirsizliği azaltıcı bir mekanizma olarak işlev gördüğünü belirtmekte, güven ve güvensizliği birbirinin yerine geçen ya da eşdeğer fonksiyonlar olarak tanımlamaktadırlar (Lewicki, McAllister ve Bies, 1998:440). Sosyolojik yaklaşım sosyal etkileşimlerdeki güvenin gözlemlenmesi ve ölçümlenmesi becerisi üzerine vurgu yapmaktadır.

Misztal sosyolojik literatürün güveni bireylere özgü, sosyal ilişkilere özgü ya da sosyal sistemlere özgü olarak kavramsallaştırdığını, bunu yaparken de eylemler üzerindeki davranışlara yönelik dikkat ve bireysel düzeyde uyumu göz önünde bulundurduğunu belirtmektedir. Bireylere özgü kavramsallaştırmada vurgu duygular, algılar ve kişisel değerler üzerindedir. Güven burada bireysel kişilik değişimlerinin bir fonksiyonu olarak görülmektedir. Bu sosyo-psikolojik çalışmalarda güven, akıl, dürüstlük, sadakat, saygı, umut, başkalarını düşünme (diğergamlık) gibi kavramlarla sıkı işbirliği içinde görülerek ilişkilendirilmiş ya da bu kavramlarla karıştırılmıştır (Misztal, 1996: 14).

Buna karşılık, sosyal ilişkilere özgü kavramsallaştırmada güven, toplumun kurumsal bir çatısı olarak görülmektedir. Güven burada belli kurumsal amaçları başarmak için sosyal bir kaynak olarak görülmektedir. Üçüncü olarak sosyal sistemlere özgü yaklaşım ise güveni, üyelerinin sürekli eylemleri sonucunda oluşan değerli bir kamusal yarar olarak görmektedir. Güven toplumsal yapının önemli bir boyutu olarak, ne psikolojik düzeyde ne de kurumsal düzeyde olmayan çünkü her ikisine de nüfuz eden bir kavram olarak görülmektedir (Misztal, 1996: 14). Bu da güvenin çok yönlü ve bütünsel bir yapısı olduğunu göstermektedir.

Rousseau güveni, başka insanların niyet ve davranışlarının, olumlu beklentilere dayalı olarak açık ve dürüst olacağını kabul etme konusundaki psikolojik durum olarak tanımlamıştır (Rousseau, 1998: 395). Hosmer ise güveni bir kişi, grup ya da kurumun ekonomik etkinlikler 
ya da müşterek işlerde etiksel olarak doğru kararlar ve hakkaniyetli bir biçimde davranacağına dair diğer kişi, grup ya da kurumun beklentisi olarak tanımlamaktadır (Hosmer, 1995: 399).

Güvenle ilgili ilk çalışmaların öncülerinden biri olan Deutsch güveni, beklentileri, şüphe ve kararsızlıkları etkileyen kişilerarası bir faktör olarak görmektedir. Aynı zamanda güvenle ilgili önceki sorunlar ve şimdiki durumların güven kavramını ve onunla bağlantılı kavramların hem sosyal yaşamı hem de kişisel gelişimi anlamak için hayati önem taşıdığını belirtmektedir (Deutsch, 1958: 265). Alanın bir diğer öncüsü olan Zand'e göre güven sadece bir duygu değil aynı zamanda birinin diğerine olan itimadındaki bilinçli düzenlemedir (Zand, 1972: 229-239).

Giddens güveni, belirli bir sonuçlar ya da olaylar kümesi göz önüne alındığında, bir kişi ya da sistemin güvenilirliğine olan itimat olarak tanımlamaktadır. Burada itimat etme-inanma (confidence) önemli bir anahtar sözcük olarak ortaya çıkmaktadır. İtimat, başkalarının dürüst olduğuna, sevgisine ya da soyut ilkelerin (teknik bilgiler) doğruluğuna yönelik olarak beslenilen inanç olarak tanımlanmaktadır (Giddens, 2004: 39-40). Basit olarak güven ve inanç arasındaki ayırıma bakıldığında, güvenin kişisel karar verme ve alternatifler arasından seçim yapmayla ilgili olduğu, örneğin "risk almaya karar verdim ve yeni meslektaşıma güveniyorum”, bir şeye ya da kimseye inanmanın ise daha çok alışkanlık sonucu olan bir beklentiyi ifade ettiği görülmektedir (Misztal, 1996:16). Güven bireyin, olasılıklar içinden seçim yaparak güvenme yönünde tercih yapmasını ifade ederken, itimat etme ya da inanma için belli bir alışkanlık kazanılması gerektiği görülmektedir.

Güvenin sözlük anlamı içinde "itimat”la birlikte, "güvence altına alınmış inanç", "sağlama alma" gibi terimler de bulunmaktadır. Güven terimi insan ilişkilerinde kullanıldığı gibi hava, demiryolu tarifeleri, arabalar gibi sosyal yaşamın içinde var olan diğer unsurlarla olan ilişkilerde de kullanılmaktadır. Güvenin tüm kullanım alanlarındaki temel esas, karşı tarafa yönelik beklenti ve tahmin edebilme unsurlarıdır. Bununla birlikte güvenmek eyleminde ise ek olarak güven duyan birey olumsuz bir durum karşısında duygusal anlamda sıkıntı yaşamaktadır (Deutsch, 1958: 265-266).

Hosmer de, farklı disiplinlerden birçok araştırmacının güven konusundaki benzer noktalardaki uzlaşımlarını şu şekilde sıralamıştır (Hosmer, 1995: 390-392):

1. Güven bir tarafın diğer tarafın davranışlarına ilişkin olumlu bir beklenti içinde olması durumunu ifade etmektedir. Güvenen taraf her zaman en iyi beklentisi içerisindedir. Bu durum güvensizliğin hakim olduğu ekonomik işlemler veya sosyal yapılarda açıkça ortaya çıkmayabilmektedir. Bu gibi 
durumlarda temkinli bireyler, herhangi bir davranış, tutum, pazar anlaşmaları, hiyerarşik kontroller, yasal gereklilikler, resmi olmayan yükümlülükler gibi konularda kendilerini korumak amacıyla en kötüsüne karşı hazırlıklı olmaktadırlar. Ancak güven bu güvensizlik durumlarının karşısında olumsuz terimlerden çok olumlu yaklaşımlar ve beklentiler arasında yer almaktadır.

2. Güven, diğer insanların ilgi ve beklentilerine ve davranışlarına bağımlı olmaktan kaynaklanan bir tür savunmasızlık koşulu altında oluşmaktadır. Güven aynı zamanda içerisinde savunmasızlığı barındırmaktadır.

3. Güven genellikle baskı ve zorlamayla değil, istek ve işbirliğiyle ve bu işbirliğinden kaynaklanan karşılıklı faydalarla ortaya çıkmaktadır.

4. Güven genellikle zorla kabul ettirilmesi güç olan bir yapı taşımaktadır. Bireysel eylemler ve kişilerarası ilişkilerin olmadığı ekonomik kontratlar, yasal gereklilikler, hiyerarşik kontroller gibi işlemler güven için pahalı vekalet özelliği taşımaktadırlar.

5. Güven tarafların birbirlerinin çıkarlarını ve haklarını korumayı bir görev olarak kabul ettikleri varsayımına dayanmaktadır. Güvenilen kişinin, grubun ya da kuruluşun yardımsever nitelikte olacağı ya da en azından zarar verici davranışlarda bulunmayacağı beklentisi güvenle ilgili tüm tartışmalarda gizli bir eğilim niteliğindedir.

Sztompka güvenin tüketimden eğitime, çalışma hayatından boş zamana kadar yaşamın bütün alanlarındaki potansiyel seçimlerde söz konusu olan önemli bir kavram olduğunu ifade etmektedir. İnsanlar ne kadar çok seçenekle karşılaşırlarsa, karar vermeleri o kadar zor olmaktadır. Alternatif eylemler arasından seçim yaparken bu ya da şu politikacıyı desteklemek, bu ya da şu doktora muayene olmak, bu üründen ziyade diğer ürünü satın almak, paranın bu bankadan ziyade diğer banka hesabına yatırılması gibi birçok durum karşısında sıklıkla güven olgusuna başvurulmaktadır. Benzer olarak, diğerlerinin eylemlerindeki belirsizlikle ilgili olarak, onların kendi çoklu seçimleri arasından hangisini seçeceklerine dair, örneğin başbakanın ne tür politikalar uygulayacağı, doktorun hangi tedaviyi uygulayacağı, şirketin ürün için hangi değeri biçeceği, bankanın paramızla nasıl yatırım yapacağı gibi durumlarda da diğerlerine duyulan güven, kişilerin eylemlerinin vazgeçilmez bir bileşenidir (Sztompka, 1999: 14). 


\subsection{Güvenin İşlevleri}

Güven toplumsal yaşam içinde birçok işleve sahip bir kavramdır. Güvene yönelik çok boyutlu incelemeler, farklı alan ve disiplinlerin güvene yönelik inceleme ve araştırmaları bunu kanıtlar niteliktedir. Sosyal ve ekonomik ilişkiler, değişim mekanizmaları, sosyal dayanışmanın sağlanmasındaki ayırt edici rolü birçok araştırmacı tarafından ortaya konmuştur.

Herhangi bir ilişki türünün gerçekleştirilmesi güven olmaksızın imkansızdır. Aynı şekilde çalışma yaşamıyla ilgili ilişkilerin de güven olmadan gerçekleştirilmesi oldukça güçtür. Güven bir seçimdir, yapılan her seçimin de bir bedeli olmaktadır ve bir bedel olduğunda da risk taşımaktadır. Her seçim diğer alternatiflerin aradan çıkarılması anlamına gelmektedir. Ekonomistler bu vazgeçilen seçimleri fırsat maliyeti olarak değerlendirmektedirler (Ward ve Smith, 2003: 18-19). Güven bütün sosyal ilişkilerde olduğu gibi ekonomik ilişkilerde de önemli bir etkendir, belli bir bedel ve risk içermekte, güvenin düşük düzeyde olduğu iş ilişskileri gerektiğinden daha fazla yazışma, iş ve zaman kaybına neden olmaktadır.

Aynı zamanda sosyolojik literatür de devamlılık taşıyan sosyal ilişkilerin sosyal düzen olmadan uzun süre devam edemeyeceğini ortaya koymaktadır. Bununla birlikte açık şekilde hem sosyal düzen hem de sosyal ilişkiler açısından güvenin önemli bir gereklilik olduğu görülmektedir. Bu kavramlardaki herhangi bir çözülme geride büyük bir külfet bırakmaktadır (Welch, Rivera v.d., 2005: 467).

Örneğin hükümete yönelik güven seçmenlerin sadece oy vermelerinde değil aynı zamanda da hükümet politikalarını desteklemelerinde, kanunlara uymalarında, politikacılara ve politik kurum ve kuruluşlara yönelik değerlendirmelerinde ve düşüncelerinde de etkili olmaktadır. Politik güvenin olmayışı demokratik hükümete yönelik desteğe zarar vermekte, hükümetin meşruiyetiyle ilgili soruların doğmasına neden olmaktadır. Kısacası güven, politikacıların etkili yönetim becerilerini de etkilemektedir (Gershtenson, Ladewig ve Plane, 2006: 882883). Güvenin başlıca işlevlerine yönelik olarak literatürde yapılan araştırmalar ve araştırmacılar da güvenin bu özelliklerini kanıtlar niteliktedirler.

Güvenin siyaset, ekonomi, sosyal ilişkiler gibi toplum düzenini oluşturan bütün ilişki yapılarında yarattığı etkiye yönelik olarak ortaya çıkan tabloda, belirsizliğin ve karmaşa durumlarının çözümlenmesinde önemli bir gereklilik olduğu, değişim durumlarında vazgeçilmez bir etkisi bulunduğu, sosyal ilişkilerde bir birleştirici işlevi gördüğü, bireyler, 
gruplar ve kurumlar arasında açıklığı sağlayarak, çatışmalara yönelik çözümler sunduğu, bütünleştirici bir yapı sağladığı ve yönetim süreciyle ilgili sorunlarda sözleşmelere ve gözetim araçlarına yönelik gerekliliği azalttığı ortaya çıkmaktadır. Güvenin bütün bu özelliklerinin farklı disiplin ve alanlardaki araştırmacılar tarafından değerlendirilmesine yönelik tablo aşağıda yer almaktadır.

Tablo 1.4. Güvenin Önemli İşlevleri ve Literatüre Bakış

\begin{tabular}{|c|c|}
\hline Önemli işlevleri & Kaynak \\
\hline $\begin{array}{l}\text { Yüksek derecede kararsızlık, belirsizlik ve } \\
\text { karmaşıklık durumlarında } \\
\text { kaçınılmazdır }\end{array}$ & $\begin{array}{l}\text { Lewis and Weigert (1985), Shapiro (1987), } \\
\text { Nooteboom (1996), Shaw (1997), Deering and } \\
\text { Murphy (1998), Lane (1998), Nahapiet and } \\
\text { Ghoshal (1998), Rousseau et al. (1998), Sako } \\
\text { (1998), Senge et al. (1999), Costa (2000), } \\
\text { Overlaet (2000) }\end{array}$ \\
\hline $\begin{array}{l}\mathrm{Bu} \text { durumlarda güvenlik hissi sağlayarak } \\
\text { varlığını sürdürmeyi sağlamaktadır }\end{array}$ & $\begin{array}{l}\text { McAllister (1995), Ellinor and Gerard (1998), } \\
\text { Ryan and Oestreich (1998), Reina and Reina, } \\
\text { (1999), Senge et al. (1999), Overlaet (2000) }\end{array}$ \\
\hline $\begin{array}{llll}\mathrm{Bu} & \text { durumlarda risk } & \text { alarak } & \text { varlığını } \\
\text { sürdürmeyi sağlamaktadır } & & \end{array}$ & $\begin{array}{l}\text { Katzenbach et al. (1995), Shaw (1997), Lewis } \\
\text { (1999), Reina and Reina (1999), Senge et al. } \\
\text { (1999), Costa (2000), Overlaet (2000) }\end{array}$ \\
\hline $\begin{array}{l}\text { Değişimi } \quad \text { gerçekleştirme } \quad \text { becerisini } \\
\text { arttırmakta ve değişimi desteklemektedir }\end{array}$ & $\begin{array}{l}\text { Argyris (1970), Katzenbach et al. (1995), Shaw } \\
\text { (1997), de Geus (1997), Deering and Murphy } \\
\text { (1998), Ellinor and Gerard (1998), Ryan and } \\
\text { Oestreich (1998), Reina and Reina (1999), Senge } \\
\text { et al. (1999), Costa (2000), Overlaet (2000) }\end{array}$ \\
\hline $\begin{array}{l}\text { Öğrenme, yaratıcılık ve yeniliklerin } \\
\text { yerleşmesinde yardımcı bir unsurdur }\end{array}$ & $\begin{array}{l}\text { Senge (1990), Ghoshal and Bartlett (1997), } \\
\text { McAllister (1997), Shaw (1997), Zand (1997), } \\
\text { Deering and Murphy (1998), Lane (1998), } \\
\text { Lazaric and Lorenz (1998), Nahapiet and } \\
\text { Ghoshal (1998), Rousseau et al. (1998), Ryan } \\
\text { and Oestreich (1998), Sako (1998), Lewis } \\
\text { (1999), Reina and Reina (1999), Senge et al. } \\
\text { (1999), Costa (2000), Overlaet (2000) }\end{array}$ \\
\hline
\end{tabular}




\begin{tabular}{|c|c|}
\hline $\begin{array}{l}\text { Sosyal ilişkilerde verimliliği artırmakta, } \\
\text { sosyal bir birleştirici görevi görmektedir }\end{array}$ & $\begin{array}{l}\text { Blau (1964), Zucker (1986), Fukuyama (1995), } \\
\text { Hosmer (1995), Deering and Murphy (1998), } \\
\text { Hollis (1998) }\end{array}$ \\
\hline $\begin{array}{l}\text { Bilginin paylaşımını teşvik ederek, ilişkileri } \\
\text { zenginleştirerek, bireyler, gruplar ve } \\
\text { kurumlararası açıklığı arttırarak, karşılıklı } \\
\text { kabulü sağlayarak, çatışmalara yönelik } \\
\text { çözümleri arttırarak ve problemlere yönelik } \\
\text { bütünleştirici, birleştirici çözümler } \\
\text { sağlayarak işbirliğini geliştirmekte ve devam } \\
\text { ettirmektedir }\end{array}$ & $\begin{array}{l}\text { Argyris (1970), Zand (1972, 1997), Deutsch } \\
\text { (1973), Zucker (1986), Shapiro (1987), Senge et } \\
\text { al. (1994, 1999), Katzenbach et al. (1995), Mayer } \\
\text { et al. (1995), Ross and LaCroix (1996), } \\
\text { (Wheatley and Kellner-Rogers 1996), Ghoshal } \\
\text { and Bartlett (1997), Shaw (1997), Deering and } \\
\text { Murphy (1998), Elangovan and Shapirio (1998), } \\
\text { Lane (1998), Rousseau et al. (1998), Ryan and } \\
\text { Oestreich (1998), Tsai and Ghoshal (1998), } \\
\text { Whitener et al. (1998), Zaheer et al. (1998), } \\
\text { Lewis (1999), Reina and Reina (1999), Costa } \\
\text { (2000) }\end{array}$ \\
\hline $\begin{array}{l}\text { Ayrıntılı olarak hazırlanmış sözleşmeli ve } \\
\text { gözetime dayalı araçlara yönelik ihtiyac1 } \\
\text { azaltmakta ve yönetim/yönetişim süreciyle } \\
\text { ilgili sorunlarda önemli bir rol oynamaktadır }\end{array}$ & $\begin{array}{l}\text { Bradach and Eccles (1989), Shaw (1997), } \\
\text { Deering and Murphy (1998), Lane (1998), } \\
\text { Rousseau et al. (1998), Zaheer et al.(1998), } \\
\text { Lewis (1999), Nooteboom (1999a), Senge et al. } \\
\text { (1999), Costa (2000), Sen (2000) }\end{array}$ \\
\hline
\end{tabular}

Kaynak: Frederique Six, The Trouble With Trust The Dynamics of Interpersonal Trust Building, Cheltenham, Edward Elgar Publishing Limited, 2005, pp. 2-3.

Güvenin literatürde belirtilen önemli işlevleri, toplumda her türlü ilişki biçiminde iletişimi kolaylaştıran, işbirliğini sağlayan, bütünleştirici olan ve dayanışmayı arttıran, işbirliğini sağlayan bir yapı sunmasıdır. Bu işlevler birbirinden bağımsız düşünülmemektedir, birbirini bütünleyen ve iç içe geçmiş işlevlerdir.

\subsection{Güven ve Kaynağın İnanılırlığı}

Güven gibi, kaynağın inanılırlığı (source credilibility) da birçok faktöre bağlı karmaşık bir olgu olarak tanımlanmakta ve Aristoteles'e kadar uzanmaktadır. Aristoteles inanılır bir kaynak için üç temel özellik tanımlamıştır: Etos (karakter ve doğruluk- character and integrity), Logos (deneyim ve yeterlilik- expertise and competence) ve Pathos (karizmacharisma). Modern araştırmalar da bu boyutları ampirik olarak desteklemektedir. Daha önceki araştırmalar kaynağın yeterliliğine daha fazla vurgu yapmıştır. İnanılırlığın oluşturulması için 
en kritik unsurlar olarak statü, itimat edilme ve deneyim gibi boyutları gösterilmiştir. Diğer araştırmalar ise önemli bir boyut olarak kaynağın güvenilirliği boyutunu eklemişlerdir. Aristoteles'in yüzyıllar önceki düşüncelerini destekler biçimde ampirik çalışmalar kaynağın inanılırlığı için üç benzer boyut ortaya koymaktadır: deneyim (expertise), güvenilirlik (trustworthiness) ve (attractiveness) çekicilik (Rawlins, 2007: 6). Yüzyıllar boyunca retorik çalışmalarında ethos yani değerler sisteminin ikna sürecinde en etkili araç olduğu Aristoteles'in görüşü dışında diğer retorik bilginleri tarafindan da desteklenmektedir. Burada iletişim çabasının amacı iknayı sağlamak ya da anlamayı geç̧ekleştirmektir. Kaynağın inanılırlığ 1 , çok boyutlu bir kavram olarak düşünülmüştür. Örneğin Aristotleles'in etos ya da kaynağın inanılırlığı kavramı içinde var olduğunu öne sürdüğü boyutlar olan akıl, karakter ve iyi niyet alıcı üzerinde etki bırakan algısal kaynaklardır (McCroskey ve Young, 1981: 24).

İnanılırlıkla ilgili çalışmalar, ikna sürecindeki rolüne olan ilgiyle başlamıştır. Araştırmacılar kişilerarası etkide kaynağın inanılırlığı konusunda çalışmalar yürütmüşler, daha sonraları ise kurumların da iletişim aracılığıyla insan davranışlarını etkilemek amacıyla ikna edici kaynaklar yarattığını gözlemlemişlerdir. Mesajın inanılırlığı da daha önceki çalışmalarda yer almış, mesajın karakteristik özelliklerinin az ya da çok inanılırlık taşımasıyla ilgili çalışmalar gerçekleştirilmiştir. Aynı zamanda da kitle iletişim araştırmaları nedeniyle medya inanılırlığıyla ilgili çalışmalar gerçekleştirilmiştir. Örneğin gazetelere karşı televizyon gibi, iletişimin belli formlarındaki inanılırlığa yönelik çalışmalar gerçekleştirilmiştir (Metzger v.d., 2003: 296).

Hovland ve Weiss tarafından güven duyulan ve güven duyulmayan kaynaktan gelen iletilerin izleyici üzerinde bıraktığı etki ile ilgili olarak bir takım deneyler gerçekleştirilmiştir. $\mathrm{Bu}$ deneylerde deneklere bir takım tartışmalı konular ve kaynaklar verilmiştir. Deneklere sunulan dört tartışmalı konu, anti-alerjik ilaçlar, atom enerjili denizaltıları, çelik yokluğu, filmlerin geleceği konularıdır. Aynı zamanda bu konularla ilgili olarak sunulan makaleler için deneklerin yarısına güvenilirliği yüksek yarısına da güvenilirliği düşük kaynaklar seçilmiştir. Konularla ilgili olarak güvenilirliği düşük kaynak olarak seçilen kişiler örneğin işçi karşıtı sağcı köşse yazarı, film dedikoduları yazan bir kadın, Rus gazetesi Pravda gibi örneklerdir. Güvenilirliği yüksek kaynak olarak ise Fortune dergisi, Ulusal Kaynakları Planlama Bürosu Bülteni gibi kaynaklardır (Hovland ve Weiss, 1951-1952: 636-650). Araştırma sonucunda güvenilirliği yüksek kaynağın dört konudan üçünde daha fazla düşünce değişikliğine yol açtığı saptanmıştır. Aynı zamanda denekler, güvenilir kaynak tarafından savunulan düşünceyi güvenilmeyen kaynak tarafindan savunulan düşünceden daha inanılır bulmuşlardır. 
İnanılırlıkla ilgili olarak gerçekleştirilen bir başka araştırmada katılımcıların yüksek ve düşük inanılırlık durumları karşısındaki tutumlarına yönelik bir deney gerçekleştirilmiştir. Buna göre katılımcılara basılı bir reklam ilanı gösterilmiş, bunun bir hükümet birimi tarafından sponsor olunarak, gözetim altında tutulan biyo-teknoloji ürünü bir bitki olduğuna inandırılmışlardır. Araştırmacılar tarafından oluşturulan başka bir düşük inanılırlık durumunda ise aynı reklam ilanının biyo-teknoloji bitkileri üzerine ticari bir şirket tarafından sponsor olunduğuna inandırılmışlardır. Sonuç olarak kar motivasyonu nedeniyle hükümet ticari kuruluştan daha inanılır bulunmuştur (Nan, 2009: 324-330).

Bentele, inanılırlığın (credibility), güven kavramının bir alt-fenomeni olduğunu, kişiler, kuruluşlar veya onların iletişimsel unsurlarıyla (yazılı ya da sözlü materyaller, görsel-işitsel sunumlar) ilgili olarak kavramsallaştırılabileceğini belirtmektedir. $\mathrm{Bu}$ özelliğiyle inanılırlık metinlerin doğasında olan bir kavram değil, çoklu konumlandırılmış ilişkiler içinde bir unsurdur (Bentele ve Seidenglanz, 2008: 3). İnanılırlık kavramının niteliği günlük dilde iletişimsel boyutuyla sınırlı olsa da, güven çok daha geniştir. Güven sadece bir etkenle ilgili ifadelerdeki çok yüksek ya da düşük güven duymakla ilgili değil, aynı zamanda nesnelerin teknik boyutlarında da (örneğin otomobiller) sosyal kurumlarda da (işsizlik sigortası, siyasal partiler), coğrafi durumlarda (hava durumu gibi) ya da sosyal sistemlerde (emeklilik sistemi, pazar ekonomisi ya da parlamenter demokrasi gibi) de kullanılan bir kavramdır (Bentele ve Seidenglanz, 2008: 3).

İnsanlar çoğu zaman güvenilir kaynaklardan aldıkları mesajları, destekleyici kanıtlara pek de önem vermeden kabullenme eğilimi içindedirler. Kaynağın güvenilirliği, iletişimin etkisinde çoğu zaman temel belirleyici olarak karşımıza çıkmaktadır. Mesajda ileri sürülen iddiaları destekleyici yeterli kanıt olmasa bile, eğer o mesaj çok güvenilir bir kaynaktan gelmekteyse, hedef tarafından benimsenmesi kolaylaşmaktadır. Mesajın ya da bilginin doğruluğunu kanıtlayacak ya da test edecek herhangi bir kanıtın olmadığı durumlarda kaynağın güvenilirliği çok daha fazla önem kazanmaktadır çünkü bu gibi durumlarda hedef, söz konusu mesajı ya da bilgiyi benimseme ve kullanma sürecinde tek bir öğeye, yani kaynağın güvenilirliğine göre hareket etmek zorundadır (İnceoğlu, 2004: 180-181). İletişim kaynağ1 değişkenleri ile yapılan alan ve laboratuar araştırmalarında çoğu kez kaynak etkilerinin bireye etkisi üzerinde durulmuştur. Deneklere belirli mesajlar yöneltilerek, mesaj kaynağı farklı olarak verilmiştir. $\mathrm{Bu}$ araştırmalarda kullanılan kaynak özellikleri arasında kaynağın karizması, uzmanlığı, çekiciliği, inanılırlığı gibi değişkenler bulunmaktadır. Kaynağın 
güvenilirliği diğer etkenlere oranla tutum değişimini daha çok etkilemektedir (İnceoğlu, 2004: $180)$.

Herhangi bir görüş ya da mesajın konunun uzmanı tarafından iddia edilmesi veya ortaya atılması da sıradan kişilerin iddiasından daha yüksek güvenilirlik taşımaktadır. Burada saygınlık özelliği kaynağın kendisine ait olabileceği gibi kanala yani taşıyıcıya da ait olabilmektedir (Özerkan ve İnceoğlu, 1997: 11). Aynı zamanda güvenin oluşması için gerekli faktörler arasında özneye yönelik bilgi, problem çözme yeterliliği, iletişim becerisi, iletişimin sürekliliği, iletişimin şeffaflığı, sosyal sorumluluk ve etiksel sorumluluk gibi unsurlar gelmektedir. Kaynak tarafından bu faktörler yerine getirildiğinde yüksek seviyede güven oluşturulurken, bu faktörlerin düşük seviyede olması ya da hiç olmaması durumu güvensizlik oluşumuna neden olmaktadır. Güven oluşumu dinamik bir süreçtir ve aynı zamanda güveni sağlamak uzun bir süreçken güvenin yok olması hızla gerçekleşebilmektedir (Bentele ve Seidenglanz, 2008: 9). Aynı zamanda kurumlara yönelik inanılırlıkta kaynak bir birey olmamakla birlikte çok daha karmaşık bir yapı taşımaktadır. Kurumun sahip olduğu deneyimlerinin tarihsel geçmişi ve bugünkü bilgi, toplum tarafindan sürekli biçimde izlenmekte ve toplum ve kurum karşı karşıya kalmaktadır. Örneğin ticari kuruluşlar için kurumlara yönelik inanılırlık reklamcılık ve pazarlama literatürü içerisinde gelişmektedir. Kurumsal inanılırlık, şirket inanılırlığı, satışı gerçekleştirenin inanılırlığı ya da reklamcının inanılırlığı kuruluşlara yönelik inanılırlık için kaynak durumundadır (Metzger v.d., 2003: 299).

\section{Sosyal Medya Kavramı}

Sosyal medya terimi kullanıcıların birbirleriyle bilgi, görüş ve ilgi alanlarını paylaşarak etkileşim kurmaları için olanak sağlayan online araçlar ve web sitelerini içermektedir. Sosyal medya, teknolojiyi, sosyal girişimciliği kelimeler, resimler, videolar ve ses dosyaları ile birleştiren şemsiye bir kavramdır. Sosyal medya ortamları, bloglar, online sohbet, RSS, sosyal ağ siteleri, sosyal imleme, forum, podcast, online sohbet ortamları, e-posta zincirleri, sanal dünyalar, wikiler gibi interaktif, kullanımı kolay, katılıma açık olan internet üzerindeki iletişim ortamlarıdır (Onat, 2010: 105). Sosyal ağ paylaşım siteleri ya da bir diğer adıyla sosyal medya siteleri içinde ülkemizde en yaygın olarak kullanılanları Facebook, Twitter, Youtube gibi sitelerdir. 


\section{Facebook}

Facebook, insanların arkadaşlarıyla iletişim kurmasını ve bilgi alış verişi yapmasını amaçlayan bir sosyal web sitesi olarak şubat 2004 tarihinde kurulmuştur. Facebook ağlardaki öğrencilerin fotoğraflar, blog mesajları (facebook notları), kişisel profiller, arkadaş grupları, e-postalar, "duvar" adı verilen ziyaretçi girişleri ve ilgi grupları aracılığıyla iletişimine olanak sağlayan bir web platformudur (Fuchs, 2008: 188).

Facebook ismini “paper facebooks"dan almaktadır. Bu form Amerika Birleşik Devletleri üniversitelerinde okulların öğrencilerine, öğretmenlere ve çalışanlara doldurduğu tanıtım amaçlı bir formdur. Son verilere göre facebook'un 800 milyondan fazla aktif üyesi bulunmakta, her bir üye ortalama olarak 130 arkadaşa sahip bulunmaktadır (http://www.facebook.com/press/info.php?statistics). Facebook giderek artan kullanıcisıyla sosyal ağ lideri konumundadır. Harvard öğrencileri için yaratılmış fakat üç yıl içerisinde küresel bir gelişim göstermiştir. Facebook kullanıcıları bulundukları şehre, çalıştıkları kuruma, okula ya da mensup oldukları bölgeye göre ağlara katılabilmektedirler. Temel bağlantı noktası davet ettiğiniz ve profil sayfalarına giriş yaptığınız arkadaşlarınızdan oluşmaktadır (Brown, 2009: $165)$.

Facebook’ta ana menü Duvar adı verilen alanı, mesajlar için açık bir alanı, fotoğraf ve videolar için ayrılan başka bir alanı kapsamaktadır. Kullanıcılar bir kısım fotoğraflarını ya da albümlerinin tamamını facebook'taki sayfalarına yükleyebilir, fotoğraflardaki insanları kim olduklarını etiketleyebilir, arkadaşlarına ne yapıyor olduğuyla ilgili bilgileri güncelleyebilmektedirler (Brown, 2009: 166). Site kullanıcılara ücretsizdir ve gelirini banner reklamlarından ve sponsor gruplarından almaktadır. Kullanıcılar profil oluşturabilmekte, kişisel bilgilerini, ilgi alanlarını, gizli ya da açık mesajlarını, arkadaş gruplarını sergileyebilmektedir. Ayrıca profillerin gösterimi sadece arkadaşlara görünecek şekilde veya belli ağların dışındakilere açık olmayacak şekilde sınırlandırılabilmektedir.

\section{Myspace}

MySpace interaktif ortamda kullanıcı kontrolünde iletişim ve arkadaşlıklar kurulabilen, kişisel profillerin, blogların, grupların, resimlerin, müzik ve videoların barındırılabileceği bir sosyal iletişim web sayfasıdır.

Myspace son zamanlardaki sosyal ağlar için bir öncü konumundadır. 2003 yılında Los Angeles temelli bir internet pazarlama şirketi olan eUniverse tarafindan kurulmuştur. Şirket 
ve Myspace 2005 yılında Rupert Murdoch tarafından satın alınmıştır. Diğer sosyal paylaşım siteleri gibi Myspace de birçok özelliğe sahiptir.

\section{Twitter}

Twitter, kullanıcılarının maksimum 140 karakterden oluşan kısa bloglar yazmasına olanak sağlayan başta gelen mikro-blog sitesidir. Titter'ın basit yapısına rağmen kullanıcılar kendileriyle ilgili bilgilerin takipçilerine ulaşabilmekte, durumlarıyla ilgili bilgi verebilmekte, iletişimin dolaysız bir formunu oluşturmaktadır. Twitter'da doğrudan ulaş1labilecek çok yüksek sayıda gazeteci ve blogcu bulunmaktadır. Aynı zamanda twitter aracılığıyla insanların ne hakkında konuştukları ve gündem de takip edilebilmektedir (Brown, 2009: 171-172).

\section{Youtube}

YouTube, 2005'te PayPal şirketinin eski çalışanları tarafından kurulmuş bir video barındırma web sitesidir. Youtube finansal gelirini sitesinde videolara eşlik eden reklamlar aracıllığıyla elde etmektedir. 2006'da Google tarafından satın alınmıştır (Fuchs, 2008: 186-187).

YouTube platformunda kullanıcılar var olan video klipleri izleyebilmekte ayrica istenildiğinde kendi video klibini YouTube'a ekleyebilmektedir. Bu platformda profesyonel içerik, film ve müzik videolarının yanı sıra kişisel klipler, TV programlarından bölümler de yer almaktadır. Aynı zamanda youtube kullanıcıları izledikleri video görüntüleri hakkında yorum yazabilmektedirler.

\section{Wikipedia}

Wikipedia (vikipedi) sanal ortamda yayınlanan, herkes tarafından üzerinde düzeltme ve ekleme yapılabilen sanal bir ansiklopedidir. 2001 tarihinde Jimmy Wales, Larry Sanger tarafından Nupedia projesine yardımcı olması amacıyla başlatılan bir projedir. Wikipedia ise daha hızlı bir içeriğe sahip olarak Nupedia'dan ayrılmıştır (Fuchs, 2008: 9). İnternetteki kullanıcılar wikipedia'ya içerik sağlamakta, editörler ise içerik denetiminden sonra bilgileri yayınlamaktadır. Vikipedi, 100'den fazla dilde hizmet vermektedir. 2005 yılı Ağustos ayı 
itibariyle İngilizce olarak yaklaşık olarak 750 bin, diğer dillerde de toplam 1 milyonu aşkın madde bulunmaktadır.

Wikipedia üzerinde sürekli ilaveler ve değişiklikler yapılmaktadır. Vikipedi sözcügü, viki ve pedi kelimelerinin birleşiminden oluşur. "Viki” sözcüğü, Hawaii dilindeki "wiki wiki" (hızlı veya bilgi amaçlı) sözcügünden türetilmiştir. "Pedi" ise, Antik Yunan Medeniyeti'nde "kapsamlı kültürel eğitim sistemi" anlamına gelen paideia kelimesinden gelmektedir (http://tr.wikipedia.org/wiki/Vikipedi). Wikipedia, çeşitli konularda ve farklı kesimler tarafından kullanılan sanal anlamda bir ansiklopedi özelliği taşımaktadır.

\section{Bloglar}

İnternet üzerinde giderek daha popüler olan weblog ya da blog olarak anılan kullanım alanları sürekli bir biçimde değiştirilerek güncellenmekte ve aynı zamanda da gönderiler ters bir kronolojik düzenlemeyle yer almaktadır. İlk blog'un Tim Bernars-Lee tarafından 1991 yılında oluşturulduğuyla ilgili iddialara rağmen, daha yaygın ve geniş bir kitle tarafindan tanınması, “weblog” adıyla 1997 yılında gerçekleşmiştir (Herring v.d., 2009).

Online bir etkinlik olarak bloglar, 1999 yılının ortalarına kadar katlanarak büyümüş ve özellikle 11 Eylül 2001 sonrasında ve Amerika'nın Irak işgali sırasında yaygın medya tarafından taban örgütlenmesi bakımından alternatif bir medya kaynağı olarak değerlendirilmiştir (Herring, 2009). Bloglar ilk olarak 2003 yılında Irak savaşında Bağdat şehri ateş altındayken, medya dar bir elitler çerçevesinden olayları anlatırken, blogcuların şehirle ilgili izlenimlerini anlatmalarıyla dikkati çekmiştir. Blogcular başından sonuna gerçeğe dayalı dolayımsız ve sınırsız bir iletişim süreciyle olayları aktarmışlardır (Rawsley, 2005: 179).

Genel olarak blog'lar sınırları olmayan üç kategoriye ayrılmışlardır. Ağırlıklı olarak metinlerden, fotoğraflardan, video ya da seslerlerden oluşmaları önem teşkil etmemektedir. Kişisel ya da profesyonel olabilmekte ya da her iki özelliğe birden de sahip olabilmektedirler. Hepsi teknolojik, siyasi ve günlük kategoriler olarak ayrilabilmektedir (Aydede, 2006: 33).

Blog'ların ortaya çıkış sebepleri arasında ana hatlarıyla bilgi ve iletişim teknolojilerindeki ilerlemeler, internet kullanımının giderek yaygınlaşması ve kullanım alanlarının farklılaşması, müşterilerin bilinçlenmesi ve daha fazla söz sahibi olmak istemeleri, web sitelerinin 
kullanımın pratikliğini yitirmesi gibi unsurlar yer almaktadır (Akar, 2006: 22). Blog'lar, kullanım alanları açısından alt kategorilere ayrılmaktadır. Bu kategoriler arasında kişisel bloglar, topluluk blogları, gazetecilik blogları ve şirketlerin kullandıkları kurumsal bloglar gibi bloglar bulunmaktadır. Bunlara kısaca değinilecek olursa (Lamshed, Berry ve Armstrong, 2009):

- Kişisel Bloglar: Bu kategorideki blog'ların en sık kullanım şekli kişisel gözlem ve bilgileri düzenleyen ve bireyler tarafından kullanılan web siteleridir. Kişisel blog'ların en iyileri, internet üzerinde herhangi bir alanda olan ilginç olay ve hikayelerin anlatıldığı ve sıklıkla güncellenen blog'lardır. $\mathrm{Bu}$ sitelerden bazıları, çok kişisel ve özel olabilmektedir. Bu nedenle genel ziyaretçilerin düzenli olarak bu siteleri ziyaret edecekleri kadar ilginç içeriklere sahip olmayabilirler. Gönderiler sadece blogger'ın kişisel ilgisine yöneliktir ve geniş kitlelerle bağlantı kurulması bakımından ilgisiz kalabilmektedir.

- Topluluk Blogları: Bu tür bloglar herhangi birinin bir link aracılığıyla ya da yorum yaparak katkıda bulunabileceği bloglardır. Bunlardan bazılarının gerçek bir grupla ilişkisi bulunmamaktadır. Topluluğun odaklandığı şey kimi zaman çok özel olabilmekte ya da belirsizlik taşıyabilmektedir. Burada amaçlanan tartışma gruplarında olduğu gibi katılım için cesaretlendirmektir. $\mathrm{Bu}$ tür bloglar insanlar arasındaki sınırları kaldırmak ve blogu daha yaygın hale getirmek amacı taşımaktadır.

- Gazetecilik blogları: Gazeteciler, blogging teknolojisini geleneksel yayım formatına göre daha fazla bilgi sağlama potansiyeline sahip olması nedeniyle istekli bir şekilde benimsemişlerdir. Bu, arkaplanda sunulan bilgi, yararlı ilgi alanı kaynaklarını, kaynaklarla ilgili materyalleri, röportajların dökümlerini veya kişisel yorumları içerebilmektedir. Günümüzde birçok gazete en iyi online haberleri, makaleleri ve analizleri günlük şeklindeki formlarda kendi bloglarında yürütmektedirler.

- Kurumsal Bloglar: Öngörülü bazı kurumlar kendi müşteri tabanlarına doğrudan ulaşabilmenin bir yolu olarak blogları kullanmaya başlamışlardır. $\mathrm{Bu}$ tür kurumların oluşturduğu blog'ların odak noktaları, belirli bir ürün hakkında veya daha genel olarak iş çözümleriyle ilgili olmaktadır.

\section{Araştırma}




\subsection{Araştırmanın Amacı}

Araştırmanın amacı, toplumsal yapı üzerinde etkili olduğu düşünülen sivil toplum örgütleri, ticari kuruluşlar ve medyaya yönelik bilgi edinmede genç kanaat önderleri olarak nitelendirilen üniversite öğrencilerinin sosyal medyayı ne ölçüde kullandıkları, ne ölçüde güvenilir ve inanılır buldukları, geleneksel kitle iletişim araçları ya da kişiler arası iletişim biçimleriyle karşılaştırıldığında sosyal medyanın güvenilirlik düzeyinin ortaya konmasıdır.

\subsection{Araştırmanın Yöntem ve Kapsamı}

Araştırmada ampirik çalışma yapılmıştır. Araştırmanın evreni Marmara Bölgesi sınırları içerisinde yer alan devlet üniversitesi statüsündeki İletişim Fakülteleridir. Toplam öğrenci sayısına göre, araştırmanın evreni 5000 kişi civarındadır. Araştırmanın kapsamı, İstanbul, Marmara, Galatasaray ve Kocaeli Üniversiteleri İletişim Fakültelerinde öğrenim gören öğrencilerle sinırlı tutulmuştur.

Araştırma örneklemi ise, \% 95 güven aralığıyla farklı popülasyon (çalışma evreni) seviyeleri için örneklem çizelgesine (Keyton, 2005: 127) göre belirlenmiş, buna göre araştırmanın örneklem alt sınırı 360 kişi olarak saptanmıştır. Araştırmaya toplam olarak 389 kişi katılmıştır. Araştırma niceliksel araştırma biçimindedir. Örneklem seçimi olasılıklı örneklem, tabakalı tesadüfi örnekleme alınarak gerçekleştirilmiştir.

Araştırmada anket tipi soru formu kullanılmıştır. Anket formu, likert tipi ölçek kullanılarak yapılandırılmıştır. Bu çerçevede genel güven duyma, güvenme sonucunda oluşan tutumlar, güven yaratan faktörler, bilgi kaynağının inanılırlığı, bilgi kaynağı kullanım sıklığıyla ilgili sorular yöneltilmiştir. Araştırma kapsamında 450 adet anket formu dağıtılmış, çalışmanın sonucunda 389 adet kullanılabilir anket değerlendirmeye alınmıştır.

Araştırma sonucunda elde edilen bilgiler Sosyal Bilimler İstatistik Programı olan SPSS 17 programında değerlendirilmiştir. Bu istatistik programına, değerlendirmeye alınan 389 yanıt formundaki soru ve cevaplar kodlanmış, kodlanan soru ve cevaplar nümerik bilgiler olarak girilmiştir.

\subsection{Araștırma Bulguları ve Değerlendirme}

Araştırmada katılımcıların demografik özelliklerine göre değerlendirilmesi, sivil toplum örgütleri, ticari kuruluşlar ve hükümete yönelik bilgi edinmede sosyal medyanın güvenilirlik 
ve inanılırlık derecesinin değerlendirilmesi, geleneksel kitle iletişim araçları ve kişilerarası iletişim biçimleriyle sosyal medya karşılaştırılmasının yapılmasıyla ilgili olarak frekans tabloları oluşturulmuş ve ANOVA analizi yapılmıştır.

Tablo 1. Cinsiyet Dağılımı

\begin{tabular}{|l|r|r|r|}
\hline & Frekans & \multicolumn{1}{|c|}{ Yüzde } & Kümülatif Yüzde \\
\hline Kadın & 178 & 45,8 & 45,8 \\
\hline Erkek & 211 & 54,2 & 100,0 \\
\hline Toplam & $\mathbf{3 8 9}$ & $\mathbf{1 0 0 , 0}$ & \\
\hline
\end{tabular}

Araştırmaya katılan öğrencilerden 211'i erkek, 178'i kadın katılımcılardan oluşmaktadır. Erkek öğrenciler örneklemin \%54,2'sini, kadın öğrenciler ise \% 45,8'ini oluşturmaktadır.

Tablo 2. Yaş Dağılımı

\begin{tabular}{|l|r|r|r|}
\hline & \multicolumn{1}{|c|}{ Frekans } & \multicolumn{1}{c|}{ Yüzde } & Kümülatif Yüzde \\
\hline $18-21$ & 208 & 53,5 & 54,3 \\
\hline $22-25$ & 162 & 41,6 & 96,6 \\
\hline $26-30$ & 11 & 2,8 & 99,5 \\
\hline 31 Yaş ve Üzeri & 2 &, 5 & 100,0 \\
\hline Yanıtsız & 6 & 1,5 & \\
\hline & $\mathbf{3 8 9}$ & $\mathbf{1 0 0 , 0}$ & \\
\hline
\end{tabular}

208 katılımcı 18-21 yaş grubu arasında, 162'si 22-25 yaş grubu arasında, 11'i 26-30 yaş grubu arasında, 2'si ise 31 yaş ve üzeri yaş grubu arasındadır. Araştırmanın en yüksek katılım 
grubu 18-21 yaş arası gruptan oluşmaktadır. 18-21 yaş arası grup, örneklemin \% 53,5'ini oluşturmaktadır.

Tablo 3. Üniversitelere Göre Dağılım

\begin{tabular}{|l|r|r|r|r|}
\hline \multicolumn{5}{|c|}{ Üniversite } \\
\hline & Frekans & Yüzde & Geçerli Yüzde & Kümülatif Yüzde \\
\hline İstanbul Üniversitesi & 113 & 29,0 & 29,0 & 29,0 \\
\hline Marmara Üniversitesi & 132 & 33,9 & 33,9 & 63,0 \\
\hline Galatasaray Üniversitesi & 23 & 5,9 & 5,9 & 68,9 \\
\hline Kocaeli Üniversitesi & 121 & 31,1 & 31,1 & 100,0 \\
\hline Toplam & $\mathbf{3 8 9}$ & $\mathbf{1 0 0 , 0}$ & $\mathbf{1 0 0 , 0}$ & \\
\hline
\end{tabular}

Katılımcıların üniversitelere göre dağılımlarına bakıldığında, 132 katılımcının Marmara Üniversitesinden, 121 katılımcının Kocaeli Üniversitesinden, 113 katılımcının İstanbul Üniversitesinden, 23 katılımcının ise Galatasaray Üniversitesi İletişim Fakültesinden olduğu görülmektedir. Marmara Üniversitesi İletişim Fakültesi öğrenci sayısı bakımından, araştırma örnekleminin \% 33,9’unu oluşturarak en büyük orana sahiptir.

Tablo 4. Sivil Toplum Örgütleri, Ticari Kuruluşlar ve Hükümete Yönelik Genel Güven Düzeyi

\begin{tabular}{|l|r|r|r|}
\hline & Sivil Toplum Örgütleri & Ticari Kuruluşlar & Hükümet \\
\hline N & 386 & 384 & 386 \\
\hline Yanıtsız & 3 & 5 & 3 \\
\hline Ortalama & $\mathbf{3 , 1 2 6 9}$ & $\mathbf{2 , 4 4 0 1}$ & $\mathbf{2 , 0 3 8 9}$ \\
\hline
\end{tabular}

Katılımcılar kurumlara güven duyma konusunda kararsız ya da olumsuz bir tutum içindedirler. Kurumlar arasında bir kıyaslama yapıldığında ise göreceli olarak sivil toplum 
örgütlerine yönelik güvenin diğer kurumlara göre daha fazla olduğu görülmektedir. Sivil toplum örgütlerinden sonra ticari kuruluşlar ve hükümet gelmektedir.

Tablo 5. Sivil Toplum Örgütleri Hakkında Bilgi Edinmede Kaynağın İnanılırlı̆̆

\begin{tabular}{|l|c|c|}
\hline & N & Ortalama \\
\hline Arkadaş ve yaşıtlarla yapılan sohbetler & 388 & $\mathbf{3 , 4 5 8 8}$ \\
\hline Sivil toplum örgütlerinin kendi web sayfası & 388 & $\mathbf{3 , 3 0 4 1}$ \\
\hline Dergilerdeki makaleler & 388 & $\mathbf{3 , 2 7 5 8}$ \\
\hline Wikipedia gibi serbest içerikli ansiklopediler & 386 & $\mathbf{3 , 2 5 6 5}$ \\
\hline Sivil toplum kuruluşu tarafından yayınlanan haber & 388 & $\mathbf{3 , 2 3 4 5}$ \\
ve iletiler & & \\
\hline Radyo haber içeriği & 388 & $\mathbf{3 , 1 0 5 7}$ \\
\hline Gazetelerdeki yazılar ve mkaleler & 387 & $\mathbf{3 , 1 0 3 4}$ \\
\hline Web temelli video paylaşım siteleri & 386 & $\mathbf{2 , 9 5 0 8}$ \\
\hline Televizyondaki sohbet programları & 385 & $\mathbf{2 , 8 7 7 9}$ \\
\hline Online mesaj panoları, forum ve haber grupları & 388 & $\mathbf{2 , 8 6 0 8}$ \\
\hline Televizyon haber içeriği & 388 & $\mathbf{2 , 8 2 4 7}$ \\
\hline Bloglar & 385 & $\mathbf{2 , 7 8 9 6}$ \\
\hline Sosyal ağ paylaşım siteleri (facebook, twitter v.b.) & 388 & $\mathbf{2 , 6 8 8 1}$ \\
\hline
\end{tabular}

Sivil toplum örgütleri hakkında bilgi edinmede bilgi kaynaklarına yönelik genel bir kararsızlık ve güvensizlik eğilimi söz konusudur. Bununla birlikte tablodaki sıralama esas alınmakta ve bilgi kaynağına duyulan inanılırlık bakımından en üst sırada "arkadaş ve yaşıtlarla yapılan sohbetler" gelmektedir. Sırasıyla, "sivil toplum örgütlerinin kendi web sayfası", “dergilerdeki makaleler", "wikipedia gibi serbest içerikli ansiklopediler", "radyo haber içeriği”, "gazetelerdeki yazılar ve makaleler", "web temelli video paylaşım siteleri”, 
"televizyondaki sohbet programları", “online mesaj panoları, forum ve haber grupları", "televizyon haber içeriği”, "bloglar" ve "sosyal ağ iletişim siteleri” gibi bilgi kaynakları yönelik inanılırlık konusunda katılımcıların kararsız bir tutum içinde oldukları görülmektedir.

Buna göre "arkadaş ve yaşıtlarla yapılan sohbetler" en yüksek inanılırlık düzeyine sahiptir. Diğer bilgi kaynaklarından farklı olarak yüzyüze iletişimin gerçekleşmesi bakımından, kitle iletişiminin söz konusu olduğu diğer bilgi kaynaklarından farklılık taşımaktadır. Bununla birlikte "sivil toplum örgütünün kendi web sayfası" ikinci sırada yer alması bakımından önem taşımaktadır. Diğer internet bilgi kaynaklarına göre daha üst sırada yer almaktadır. "Dergilerdeki makaleler" ve "wikipedia gibi ansiklopediler”in inanılırlık bakımından görece olarak daha üst sıralarda yer alması, katılımcıların bilgi içerikli bilgi kaynaklara yönelik olarak daha olumlu bir tutum içinde olduklarına işaret etmektedir. Televizyon, radyo ve gazete gibi geleneksel iletişim araçlarının daha düşük inanılırlık oranlarına sahip olduğu görülmekte, genç katılımcılar tarafından sıklıkla kullanılan bloglar, sosyal ağ iletişim siteleri, forumlar gibi internet katılım biçimlerinin de sivil toplum örgütleri hakkında bilgi edinmede inanılırlık düzeylerinin düşük olması dikkat çekmektedir.

Sivil toplum örgütlerinin yoğun olarak hedef kamularına ne tür kitle iletişim araçlarıyla ulaştıkları da önem taşımaktadır. Sivil toplum örgütlerinin genç katılımcıların sıklıkla kullandıkları internet katılım biçimleri arasında yer alan bloglar, online mesaj panoları, forumlar, sosyal ağ iletişim sitelerinde sunduğu içerik, bilgi edinme aracı olarak katılımcılar tarafından inanılır bulunmamıştır.

Tablo 6. Hükümet Hakkında Bilgi Edinmede Kaynağın İnanılırlığı

\begin{tabular}{|l|c|r|}
\hline & N & Ortalama \\
\hline Wikipedi gibi serbest içerikli sanal ansiklopediler & 388 & $\mathbf{2 , 7 5 7 7}$ \\
\hline Bloglar & 387 & $\mathbf{2 , 5 7 6 2}$ \\
\hline Gazetelerdeki yazılar ve makaleler & 389 & $\mathbf{2 , 5 4 5 0}$ \\
\hline Online mesaj panoları, forum ve haber grupları & 387 & $\mathbf{2 , 5 3 2 3}$ \\
\hline Web temelli video paylaşım siteleri & 388 & $\mathbf{2 , 5 3 6 1}$ \\
\hline
\end{tabular}




\begin{tabular}{|l|c|c|}
\hline Radyo haber içeriği & 387 & $\mathbf{2 , 5 1 9 4}$ \\
\hline Televizyonlardaki sohbet programları & 389 & $\mathbf{2 , 5 1 6 7}$ \\
\hline Sosyal ağ paylaşım siteleri (facebook, twitter v.b.) & 387 & $\mathbf{2 , 4 0 0 5}$ \\
\hline Hükümet yetkililerinin açıllamaları & 388 & $\mathbf{2 , 3 4 7 9}$ \\
\hline $\begin{array}{l}\text { Hükümete bağlı kurum ve kuruluşların web } \\
\text { sayfaları }\end{array}$ & 388 & $\mathbf{2 , 3 0 6 7}$ \\
\hline Televizyon haber içeriği & 389 & $\mathbf{2 , 2 5 9 6}$ \\
\hline $\begin{array}{l}\text { Hükümet tarafından kullanılan ilan, billboard, afişş } \\
\text { gibi materyaller }\end{array}$ & 388 & $\mathbf{2 , 2 6 2 9}$ \\
\hline
\end{tabular}

Genel olarak hükümet hakkında bilgi edinme belirtilen bilgi kaynaklarına yönelik bir güvensizlik eğilimi söz konusudur. Bu genel eğilim içinde değerlendirildiğinde ise hükümet hakkında bilgi edinmede “wikipedia gibi serbest içerikli sanal ansiklopediler”in inanılırlık bakımından ilk sırada yer aldığı görülmektedir. Bireylerin gönüllü olarak bilgi paylaşımı esasına dayanan ve üzerinde bilgi ekleme, çıkarma, düzenleme yapılabilen sanal bir ansiklopedi olarak nitelendirilen wikipedia'nın ardından yine bireylerin kendi iradeleriyle, yorumlarıyla oluşturdukları bir diğer internet katılım biçimi olan "bloglar” gelmektedir. Bunu geleneksel medya araçları arasında yer alan "gazetelerdeki yazılar ve makaleler" izlemektedir. "Online mesaj panoları, forum ve haber gupları", "web temelli video paylaşım siteleri” gibi internet bağlantılı kullanım biçimleri, "radyo haber içeriği”, "televizyonlardaki sohbet programları” gibi bilgi kaynaklarına yönelik inanılırlık eğilimi de düşüktür. En düşük inanılırlık "televizyon haber içeriği” ve "hükümet yetkililerinin açıklamaları", "hükümete bağlı kurum ve kuruluşların web sayfaları", "hükümet tarafından kullanılan ilan, billboard, afis v.b materyalleri” gibi bilgi kaynaklarına yöneliktir. Katılımcılar bu kaynaklardan gelen bilgileri inanılır bulmama eğilimi içindedirler. Bu bilgi kaynaklarının taraflılığı ve ikna etme, yönlendirme amacı taşıyor olması inanılırlık düzeyini ters yönde etkilemektedir. Katılımcıların daha çok bilgi içerikli kaynakları inanılır bulma eğilimi içinde oldukları görülmektedir.

Hükümet tarafından uygulanan iletişimde siyasal mesajın gönderildiği kitlenin/seçmenlerin özelliklerinin bilinmesi, verilmek istenen mesajın doğru araçlarla aktarılması, kullanılan dil, 
semboller gibi unsurlar büyük önem taşımaktadır. Aynı zamanda hükümet, diğer siyasal aktörlere karşı medyanın ve dolayısıyla seçmenlerin dikkatinin çekilmesi konusunda rekabet halindedir. Bu bağlamda siyasal iletişim sürecinde medya etkin bir şekilde kullanılmakta, yazılı basın, radyo ve televizyonun yanısıra internet gibi yeni medya olanaklarından da yararlanılmaktadır. Ancak katılımcılar hükümetin kullandığı bilgi kaynaklarına yönelik olarak kararsız ya da olumsuz bir tutum içindedirler. Hükümetin kullandığ 1 iletişim süreci araçlarının genç katılımcılar açısından başarıya ulaşmadığı söylenebilir.

Tablo 7. Ticari Kuruluşlar Hakkında Bilgi Edinmede Kaynağın İnanılırlığı

\begin{tabular}{|l|c|c|}
\hline & $\mathrm{N}$ & Ortalama \\
\hline Arkadaş ve yaşıtlarla yapılan sohbetler & 388 & $\mathbf{3 , 4 2 5 3}$ \\
\hline Wikipedia gibi serbest içerikli ansiklopediler & 386 & $\mathbf{3 , 3 3 6 8}$ \\
\hline Ekonomi dergilerindeki makaleler & 384 & $\mathbf{3 , 2 2 1 4}$ \\
\hline Gazetelerdeki yazılar ve makaleler & 388 & $\mathbf{3 , 0 4 1 2}$ \\
\hline Web temelli video paylaşım siteleri (youtube v.b.) & 386 & $\mathbf{2 , 9 3 5 2}$ \\
\hline Radyo haber içeriği & 388 & $\mathbf{2 , 9 3 0 4}$ \\
\hline Şirket tarafından yayınlanan haber ve iletiler & 386 & $\mathbf{2 , 8 5 7 5}$ \\
\hline Şirketin kendi web sayfası & 386 & $\mathbf{2 , 8 4 9 7}$ \\
\hline Online mesaj panoları forum ve haber grupları & 388 & $\mathbf{2 , 8 3 2 5}$ \\
\hline Bloglar & 386 & $\mathbf{2 , 8 1 3 5}$ \\
\hline Televizyondaki sohbet programları & 389 & $\mathbf{2 , 7 0 1 8}$ \\
\hline Televizyon haber içeriği & 389 & $\mathbf{2 , 6 1 7 0}$ \\
\hline Kurum ya da ürün reklamları & $\mathbf{2 , 5 6 5 1}$ \\
\hline Sosyal ă̆ paylaşım siteleri (Facebook, twitter v.b.) & $\mathbf{2 , 5 5 9 6}$ \\
\hline
\end{tabular}


Ticari kuruluşlar hakkında bilgi edinme kaynaklarına yönelik olarak da genel bir kararsızlık ve güvensizlik eğilimi söz konusudur. Bu tablo içinde değerlendirildiğinde diğer kuruluşlar hakkında bilgi edinmede olduğu gibi ilk sırada, arkadaşlar ve yaşıtlarla yapılan sohbetler yer almaktadır. İkinci sırada wikipedia gibi serbest içerikli ansiklopediler gelmektedir. Ekonomi dergilerindeki makaleler, gazetelerdeki yazılar ve makaleler inanılırlık bakımından ortalama bir düzeye sahiptir. Sırasıyla web temelli video paylaşım siteleri (youtube v.b.), radyo haber içerikleri, şirketlerin yayınladığı basın bültenleri, faaliyet raporları, şirketin kendi kurumsal web sayfası, online mesaj panoları ve haber grupları, bloglar, televizyon sohbet programları ve televizyon haber içeriği gibi bilgi kaynakları da inanılırlık bakımından düşük seviyededir. Kurum ya da ürün reklamları, sosyal ağ iletişim siteleri ise güven eğiliminin en az olduğu bilgi kaynakları arasında yer almaktadırlar.

Bununla birlikte araştırmamızdaki katılımcıların genel olarak bilgi kaynağına yönelik inanılırlık düzeylerinin, ele alınan bütün kurumlar bakımından kararsızlık seviyesinde ya da düşük seviyede olduğu görülmektedir. Genç kanaat önderleri olarak nitelendirilebilecek katılımcıların belirlenen kurum ve kuruluşlarla ilgili bilgi kaynağına yönelik inanma eğilimi yüzyüze iletişim biçimi olan arkadaş ve yaşıtlarla sohbetler ya da geleneksel medya dışında yer alan iletişim araçlarına yöneliktir. Bu iletişim araçları kapsamında da özellikle bilginin kullanıcılar tarafından hiçbir ticari amaç ya da çıkar söz konusu olmaksızın paylaşıldığı ve kullanıcının müdahalesine ve katılımına açık katılım biçimleri gelmektedir.

Araştırmaya katılanların sivil toplum örgütleri, hükümet ve ticari kuruluşlara yönelik bilgi kaynaklarını kullanım sıklığına bakıldığında katılımcılardaki bilgi kaynağı kullanımına yönelik genel eğilim, arkadaş ve yaşıtlarla yapılan sohbetlerin daha sıklıkla olduğu yönündedir.

Tablo 8. Sivil Toplum Örgütleri Hakkında Bilgi Edinmede Bilgi Kaynağının Kullanım Sıklığı

\begin{tabular}{|l|r|r|}
\hline & N & Ortalama \\
\hline Arkadaş ve yaşıtlarla yapılan sohbetler & 388 & $\mathbf{3 , 4 9 7 4}$ \\
\hline Dergilerdeki yazılar ve makaleler & 388 & $\mathbf{3 , 3 4 0 2}$ \\
\hline Sivil toplum kuruluşunun kendi web sayfası & 385 & $\mathbf{3 , 3 2 2 1}$ \\
\hline
\end{tabular}




\begin{tabular}{|l|r|r|}
\hline Gazetelerdeki yazılar & 388 & $\mathbf{3 , 3 1 4 4}$ \\
\hline Televizyon haberleri & 388 & $\mathbf{3 , 2 9 6 4}$ \\
\hline $\begin{array}{l}\text { Sivil toplum kuruluşu tarafından yayınlanan haber ve } \\
\text { iletiler }\end{array}$ & 387 & $\mathbf{3 , 2 3 0 0}$ \\
\hline Televizyondaki sohbet programları & 385 & $\mathbf{3 , 0 1 5 6}$ \\
\hline Wikipedia gibi serbest içerikli ansiklopediler & 385 & $\mathbf{2 , 9 7 9 2}$ \\
\hline Radyo haberleri & 387 & $\mathbf{2 , 7 4 6 8}$ \\
\hline Online mesaj panoları, forum ve haber grupları & 387 & $\mathbf{2 , 6 4 6 0}$ \\
\hline Youtube gibi web temelli video paylaşım siteleri & 385 & $\mathbf{2 , 5 8 1 8}$ \\
\hline Bloglar & 387 & $\mathbf{2 , 5 0 3 9}$ \\
\hline Sosyal ağ paylaşım siteleri (MySpace, facebook v.b.) & 386 & $\mathbf{2 , 4 9 4 8}$ \\
\hline
\end{tabular}

Katılımcılar tarafından sivil toplum örgütleri hakkında bilgi edinmede en sıklıkla kullanılan bilgi kaynağı, aynı zamanda en çok inanılırlık taşıyan "arkadaş ve yaşıtlarla yapılan sohbetler" olmaktadır. Dergilerdeki yazılar ve makaleler ise kullanım sıklığı bakımından ikinci sırada yer almaktadır. Sivil toplum örgütlerinin web sayfaları inanılırlık bakımından ikinci sırada olmakla birlikte, kullanım sıklığı bakımından üçüncü sırada yer almaktadır. Bununla birlikte gazetelerdeki yazılar ve televizyon haberleri düşük inanılırlık taşımasına rağmen kullanım sıklığı bakımından üst sıralarda yer almaktadır. Sivil toplum örgütü tarafından yayınlanan haber ve iletiler ise katılımcılar tarafından kullanım sıklığı bakımından ortalama seviyede yer almaktadır. Katılımcılar bloglar, video paylaşım siteleri, sosyal ağ paylaşım siteleri gibi internet kaynaklarını da sivil toplum örgütleriyle ilgili olarak bilgi edinmede az kullanma eğilimi göstermektedirler. Bu örgütlerle ilgili olarak en çok kullanılan internet içerikli bilgi kaynağı, örgütün kendi web sayfası olmaktadır.

Tablo 9. Hükümet Hakkında Bilgi Edinmede Bilgi Kaynağının Kullanım Sıklığı

\begin{tabular}{l|l} 
N & Ortalama
\end{tabular}




\begin{tabular}{|c|c|c|}
\hline Arkadaş ve yaşıtlarla yapılan sohbetler & 387 & 3,5452 \\
\hline Televizyon haberleri & 389 & 3,3548 \\
\hline Gazetelerdeki yazılar & 388 & 3,5026 \\
\hline Televizyondaki sohbet programları & 388 & 3,1289 \\
\hline $\begin{array}{l}\text { Hükümet yetkililerinin açıklamaları (basın } \\
\text { açıklamaları, demeçler v.b) }\end{array}$ & 389 & 2,8252 \\
\hline Radyo haberleri & 387 & 2,7804 \\
\hline Wikipedia gibi serbest içerikli ansiklopediler & 386 & 2,7694 \\
\hline Hükümete bağlı kurum ve kuruluşların web sayfaları & 388 & 2,5129 \\
\hline Online mesaj panoları, forum ve haber grupları & 389 & 2,5090 \\
\hline $\begin{array}{l}\text { Hükümet tarafindan kullanılan ilan, billboard, afiş } \\
\text { gibi materyaller }\end{array}$ & 389 & 2,4704 \\
\hline Youtube gibi web temelli video paylaşım siteleri & 389 & 2,3599 \\
\hline Bloglar & 389 & 2,2802 \\
\hline Sosyal ağ paylaşım siteleri (Facebook, MySpace v.b.) & 389 & 2,2237 \\
\hline
\end{tabular}

Hükümet hakkında bilgi edinmede en sıklıkla kullanılan bilgi kaynağı, sivil toplum örgütlerinde olduğu gibi arkadaş ve yaşıtlarla yapılan sohbetlerdir. Yüzyüze iletişim biçiminin bir türü olan sohbetlerden sonra, televizyon haberleri, televizyon sohbet programları ve gazetelerdeki yazılar gibi geleneksel kitle iletişim araçları, hükümet hakkında bilgi edinmede en sıklıkla başvurulan araçlardır. Genç katılımcıların sıklıkla kullandıkları internet içerikli araçların, hükümet hakkında bilgi edinmede çok sık kullanılmadığı görülmektedir. Aynı zamanda hükümet yetkililerinin açıklamaları, hükümet tarafından kullanılan ilan, billboard, afiş gibi araçlar da katılımcıların kullanım sıklığı bakımından alt sıralarda yer almaktadır.

Tablo 10. Ticari Kuruluşlar Hakkında Bilgi Edinmede Kaynağın Kullanım Sıklığı 


\begin{tabular}{|l|c|c|}
\hline & $\mathrm{N}$ & Ortalama \\
\hline Arkadaş ve yaşıtlarla yapılan sohbetler & 388 & $\mathbf{3 , 5 8 2 5}$ \\
\hline Gazetelerdeki yazılar & 388 & $\mathbf{3 , 2 6 8 0}$ \\
\hline Kuruluşun web sayfası & 388 & $\mathbf{3 , 3 1 7 8}$ \\
\hline Televizyon haberleri & 388 & $\mathbf{3 , 2 1 6 5}$ \\
\hline Kurum ya da ürün reklamları & 388 & $\mathbf{3 , 1 8 0 4}$ \\
\hline $\begin{array}{l}\text { Kuruluşun kendisi tarafından yayınlanan haber ve } \\
\text { iletileri (basın bülteni, faaliyet raporları, basın } \\
\text { bültenleri v.b) }\end{array}$ & 389 & $\mathbf{3 , 0 0 0 0}$ \\
\hline Wikipedia gibi serbest içerikli ansiklopediler & 389 & $\mathbf{2 , 9 7 4 3}$ \\
\hline Televizyondaki sohbet programları & 387 & $\mathbf{2 , 9 0 4 6}$ \\
\hline Ekonomi dergilerindeki yazılar & 388 & $\mathbf{2 , 9 0 4 6}$ \\
\hline Online mesaj panoları, forum ve haber grupları & 388 & $\mathbf{2 , 7 5 2 6}$ \\
\hline Youtube gibi web temelli video paylaşım siteleri & 389 & $\mathbf{2 , 6 2 2 1}$ \\
\hline Radyo haberleri & 386 & $\mathbf{2 , 6 0 3 6}$ \\
\hline $\begin{array}{l}\text { Bloglar } \\
\text { Myruluşun hisse senetleri veya endüstri analiz }\end{array}$ & 388 & $\mathbf{2 , 2 9 6 4}$ \\
\hline
\end{tabular}

Ticari kuruluşlar hakkında bilgi edinmede de en sıklıkla başvurulan, arkadaş ve yaşıtlarla yapılan sohbetlerdir. İncelenen her üç kurumda da sıklıkla başvurulan kaynağın, kendi yaşıtları veya arkadaşlarıyla olan birebir iletişim olduğu görülmektedir. Bununla birlikte, gazetelerdeki yazılar da kullanım sıklığı bakımından ilk sıralarda yer almaktadır. Ticari kuruluşların web sayfalarının da genç katılımcılar tarafından sıklıkla ziyaret edildiği görülmektedir. Ancak bu tür web sayfalarının inanılırlık bakımından daha alt seviyelerde olduğu görülmektedir. Kuruluşun hisse senetleri ve endüstri raporları gibi daha formel iletişim 
biçimleri kullanım sıklığı bakımından oldukça az kullanılan bilgi kaynakları arasında yer almaktadır.

Ticari kuruluşlar tarafından önemli bir iletişim faaliyeti olarak görülen, hem zaman hem bütçe bakımından oldukça önem taşıyan kurum ve ürünlere yönelik reklamların katılımcılar tarafından sıklıkla kullanıldığı ancak inanılırlık bakımından ele alındığında en alt sıralarda yer aldığı görülmektedir.

\section{Sonuç}

Sosyal medya kullanımının ve etkisinin her alanda hızlı yükselişine tanık olduğumuz bugünlerde özellikle genç kanaat önderleri olarak nitelendirebileceğimiz üniversite öğrencilerinin sivil toplum örgütleri, hükümet ve ticari kuruluşlarla ilgili bilgi edinmede sosyal medyayı ne ölçüde güvenilir bir kaynak olarak değerlendirdikleriyle ilgili olarak yaptığımız araştırmada çarpıcı olarak bir yüzyüze iletişim biçimi olan "arkadaş ve yaşıtlarla yapılan sohbetler"in en güvenilir ve inanılır bilgi kaynağı olduğu görülmektedir.

Sivil toplum örgütlerine yönelik bilgi edinmede en yüksek güven ve inanılırlık arkadaş ve yaşıtlarla yapılan sohbetlerken en düşük güven ve inanılırlık sosyal medyaya yöneliktir. Bununla birlikte bu bilgi kaynaklarının kullanım sıklığına bakıldığında da en sık kullanılan bilgi kaynağının arkadaş ve yaşıtlarla yapılan sohbetler, en az kullanılan bilgi kaynağının ise sosyal ağ paylaşım siteleri olduğu görülmektedir.

Aynı şekilde ticari kuruluşlara yönelik bilgi edinmede de arkadaş ve yaşıtlarla yapılan sohbetler en güvenilir ve inanılır bilgi kaynağı iken sosyal ăg paylaşım siteleri en az inanılırlık ve güven içeren bilgi kaynağı olmaktadır. Ticari kuruluşlarla ilgili bilgi edinmede bilgi kaynağının kullanım sıklığı da aynı paralel doğrultusundadır. En sık kullanılan bilgi kaynağı arkadaş ve yaşıtlarla yapılan sohbetlerken en az kullanılan bilgi kaynağı ise sosyal medyadır.

Hükümete yönelik bilgi kaynağının inanılırlığı ve güven konusunda en yüksek inanılırlık wikipedia ve bloglara yöneliktir. En düşük inanılırlık düzeyi facebook, twitter ya da myspace gibi sitelere yöneliktir. En sık başvurulan bilgi kaynağı ise arkadaş ve yaşıtlarla yapılan sohbetlerdir. En az güven duyulan bilgi kaynağı ise sosyal medyadır. 
Bilgi kaynağının kullanım sıklığı, bilgi kaynağına duyulan inanılırlığı ve dolayısıyla da güven duyma tutumunu doğrudan etkilememektedir. Katılımcılar tarafından sıklıkla başvurulan bilgi kaynakları, inanılırlık düzeyi bakımından alt seviyelerde yer alabilmektedir. Kurum ve kuruluşların hedef kamuları üzerinde güven duyma tutumunu yaratabilmeleri, bilgi kaynaklarını güvenin alt unsurları olan bağlılık, yeterli olma, bütünlük, inanılırlık, saygınlık gibi özellikleri karşılaması gerekmektedir.

Sonuç olarak bilgi kaynağının kullanım sıklığı açısından değerlendirilen kurum ve kuruluşlara yönelik bilgi kaynaklarının kullanım sıklığı, ele alınan kuruma göre değişim göstermektedir. Genel eğilime bakıldığında hükümet, ticari kuruluşlar ve sivil toplum örgütleriyle ilgili olarak bilgi edinme kaynağı olarak sosyal medyanın geleneksel kitle iletişim araçlarına oranla daha az güvenilir ve inanılır bir bilgi kaynağı olarak değerlendirildiği, en güvenilir bilgi kaynağı olarak ise kişiler arası iletişim biçimi olan yüz yüze iletişimden olarak değerlendiridiği görülmektedir.

\section{KAYNAKÇA}

Akar, Erkan (2006), Pazarlamanın Yeni Silahı Blogla Pazarlama, İstanbul: Tiem Yayınları.

Aydede, Ceyda (2006), Sanal Ortam Günlükleriyle Blog Çağı, İstanbul: Hayat Yayınları.

Bentele, Günter ve R. Seidenglanz (2008), "Trust and Credibility-Prerequisites for Communication Management", 6th International Symposium Communication in the Millennium, May 14-16, Volume 1, pp. 3-15.

Brown, Rob (2009), Public Relations and the Social Web, London: Kogan Page.

Demir, Ömer ve Mustafa Acar (2005), Sosyal Bilimler Sözlüğü, Ankara: Adres Yayınları.

Deutsch, Morton (1958), “Trust and Suspicion”, Journal of Conflict Resolution, Vol. 2, No.4, December.

Fuchs, Christian (2008), Internet and Society: Social Theory in the Information Age, New York: Routledge.

Giddens, Antony (2004), Modernliğin Sonuçları, Çev. Ersin Kuşdili, İstanbul: Ayrıntı Yayınları.

Gershtenson, Joseph ve Jeffrey Ladewig, Dennis L. Plane (2006), "Parties, Institutional Control, and Trust in Government", Social Science Quarterly, Volume 87, No.4, December. 
Hosmer, Laure Tone (1995), “Trust: The Connecting Link Between Organizational Theory and Philosophical Ethics", Academy of Management Review, Vol.20, No.2.

Hovland, Carl I. ve Walter Weiss (1951-1952), "The Influence of Source Credibility on Communication Effectiveness", The Public Opinion Quarterly, Winter, Vol.15, No.4, pp. 636-650.

İnceoğlu, Metin (2004), Tutum Alg1 İletişim, Ankara: Elips Kitap.

Keyton, Joann (2005), Communication Research Asking Questions, Finding Answers, New York: McGrawHill Publish.

Lewicki, Roy. J. ve Daniel J. McAllister, Robert J. Bies (1998), “Trust and Distrust: New Relationships and Realities", Academy of Management Review, Vol.23, No.3.

Metzger Miriam J. v.d. (2003), "Credibility for the 21st Century: Integrating Perspectives on Source, Message and Media Credibility in Contemporary Media Environment", Communication Yearbook 27, Ed. by. Pamela J. Kalbfleisch.

McCroskey, James C. ve Thomas J. Young (1981), "Ethos and Credibility: The Construct and Its Measurement After Three Decades" Central States Speech Journal, Volume 32, Spring.

Misztal, Barbara A. (1996), Trust in Modern Societies, Cambridge: Polity Press.

Nan, Xiaoli (2009), "The Influence of Source Credibility on Attitude Certainty: Exploring the Moderating Effects of Timing of Source Identification and Individual Need for Cognition", Psychology \& Marketing, Vol. 26, No.4, April, pp. 324-330.

Özerkan, Şengül ve Yasemin İnceoğlu (1997), İletişimde Etkileme Süreci, İstanbul: Pan Yayınc1lık.

Rawlins, Brad L. (2007), Trust and PR Practice, Published by the Institute for Public Relations.

Rawsley, Gary D. (2005), Political Communication and Democracy, London: Palgrave Macmillan.

Rousseau, Denise M. v.d.(1998), "Not so Different After All: A Cross-Discipline View of Trust", Academy of Management Review, Vol.23, No.3, July.

Six, Frederique (2005), The Trouble With Trust The Dynamics of Interpersonal Trust Building, Cheltenham: Edward Elgar Publishing Limited.

Sztompka, Piotr (1999), Trust, Cambridge: Cambridge University Press. 
Ward, Aidan ve John Smith (2003), Trust and Mistrust Radical Risk Strategies in Business Relationship, West Sussex: Wiley.

Welch, Michael R. ve Roberto E. N. Rivera v.d. (2005), "Determinants and Consequences of Social Trust", Sociological Inquiry, Volume 75, No.4, November.

Zand, Dale E. (1972), "Trust and Managerial Problem Solving", Administrative Science Quarterly, Vol:17, pp. 229-239.

\section{İnternet Kaynakları}

Herring, Susan C. v.d., "Weblogs as a Bridging Genre", http://portal.colman.ac.il/users/www/86/Weblogs.pdf, Erişim Tarihi, 03.09.2009.

Reece Lamshed, Marsha Berry, Laurie Armstrong, "Blogs Personal E-learning Spaces", http://www.binaryblue.com.au/docs/blogs.pdf\#search, Erişim Tarihi, 03.09.2009.

http://www.facebook.com/press/info.php?statistics, Erişim Tarihi, 01 Ekim 2011.

http://tr.wikipedia.org/wiki/Vikipedi, Erişim tarihi, 31 Ağustos 2009. 